\title{
ROYAL SOCIETY
}
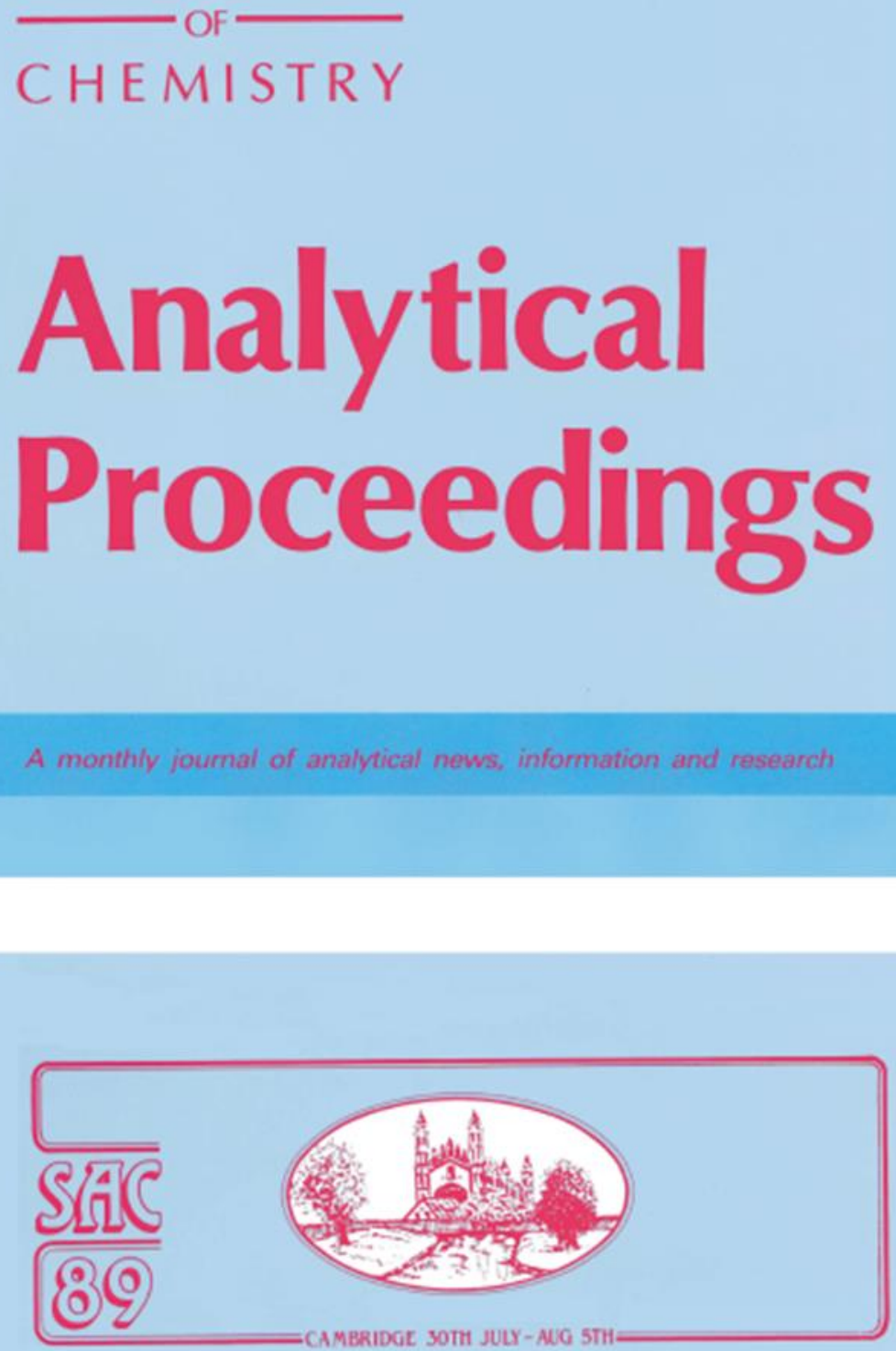

IUPAC

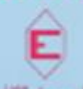

Reproduced from Anal. Proc., 1989, 26, X021, with permission from The Royal Society of Chemistry. 
Lady Mitchell Chromatography

Hall (A)

\section{Chairman: P. J. Houghton}

A9 10.30-10.55 Invited lecture. V. Schurig. University of Tubingen: "Separation of isotopic and enantiomeric compositions by complexation gas chromatography."

Al0 11.00-11.25 "Gas chromatographic separation of hydrocarbons on chitin and chitosan as stationary phases." Jama Tuddin Mohd Daud and Harry Agusnar (Universiti Kebangsaan. Malavsia).

All 11.30-11.55 "Pyrolysis gas chromatography of sepat rated zones on thin layer chromatograms. S. J. Lvele (King Fahd University of Pet roleum and Minerals. Dhahran. Saudi Arabia).

A12 12.00-12.25 "Gas chromatographic determination of dibutyltin and dioctsltin dichlorides as hydride derivatives." Sinikka Vainiotalo and Leila Hayri (Institute of Occupational Health. Helsinki. Finland).

A13 $15.00-15.25$ "Selectivity and column comparisons in
B12 12.00-12.25 "Evaluation of a new sodium selective electrode," Martin Telting, Malcolm R. Smyth and Dermot Diamond (NIHE. Dublin), Eileen Seward, Gyula Svehla and Anthony M. McKervey (University College. Cork)

B13 15.00-15.25 "Development of an optical fibre aluminium sensor in a flowing system," $E$. Blanco Gonzalez. R. Perciro Garcia, M. E. Diaz Garcia, A. Sanz-Medel (University of Oviedo. Spain), and R. Narayanaswamy (UMIST. Manchester)

BI+ 15.30-15.55 "Sensors based on polymer modified electrodes," Malcolm R. Smyth. Donal Leech Mary Meaney and Johannes G. Vos Mary Meaney and Johannes G. Vos
(NIHE. Dublin). Pilar Domingucz. JoseMaria Fernandez Alvarez and Tuno Blanco (University of Oviedo, Spain).

B 15 16.00-16.25 "The preparation of polypyrrole layers for $\mathrm{NO}_{\mathrm{r}}$ gas sensors," Jonathan M. Slater and Esther Watt (Birkbeck College, London).

B16 16.30-16.55 "Development of a test rig for evaluating metal oxide gas sensors in solvent analysis."

Reproduced from Anal. Proc., 1989,26, 185-195,

with permission from The Royal Society of Chemistry. 


\title{
SENSORS BASED ON POLYMER MODIFIED ELECTRODES
}

\author{
Malcolm R. Smyth, Donal Leech, Mary Meaney, Johannes G. Vos \\ School of Chemical Sciences, NIHE Dublin, Glasnevin, Dublin 9, Ireland \\ Pilar Domínguez, José María Fernández Álvarez, Paulino Tuñón Blanco \\ Department of Analytical Chemistry, University of Oviedo, Oviedo, Spain
}

The application of polymer modified electrodes as sensors for a range of inorganic and organic species is of increasing interest in analytical chemistry. In recent years, our studies have concentrated on the development of polymer modified electrodes based on $\left[\mathrm{Ru}(\mathrm{bpy})_{2}(\mathrm{PVP})_{5} \mathrm{Cl}\right] \mathrm{Cl}$ as detection systems in flow injection analysis ${ }^{1,2}$ and on the incorporation of antibody species, such as anti-human serum albumin, into polypyrrole ${ }^{3}$. This paper will review the recent results that we have obtained using novel rutheniumcontaining polymers, and on the further studies on the incorporation of proteins into polymeric matrices.

\section{References}

1. Barisci JN, Wallace GG, Wilke E, Meaney M, Smyth MR and Vos JG, Electroanalysis, in the press.

2. Meaney M, Smyth MR, Vos JG and Wallace GG, Electroanalysis, submitted for publication.

3. John R, Wallace GG and Smyth MR, Biosensors, submitted for publication. 